\title{
Femoral head disengagement from Accolade femoral stem in MOM Arthroplasty: a case study and literature review
}

\author{
Mohamed F. H. Elsheikh* and Rehan Gul \\ Department of Trauma and Orthopaedic, Cork University Hospital, Wilton, Cork, Republic of Ireland
}

Received 8 May 2019, Accepted 19 July 2019, Published online 20 August 2019

\begin{abstract}
Background: Metal on Metal Hip arthroplasty was commonly used until the last decade. However Hip Arthroplasty registries of many countries showed increased revision rates of MOM Hips - these high rates of revision caused by trunnionosis, adverse tissue reactions (ALTRs) and Pseudotumor formation.

The Case: Our Case is 73 years old gentleman who had left MOM THR in 2008, and was doing fine till the beginning of 2018 when his left leg stuck while getting out of the car. Despite he heard the pop and his leg was shortened and externally rotated, but he was still walking on it for a while. On reviewing him in our orthopedic clinic and after getting the CT-scan showed that he had dislocated femoral head from the stem.
\end{abstract}

Key words: Metal on Metal Arthroplasty, Trunnionosis, Pseudotumor.

\section{Introduction}

Metal-on-metal (MOM) total hip arthroplasty using cobaltchrome alloy has been in use since the 1960s as a stemmed replacement [1]. It was popularized due to its enhanced wear profile and the ability to use large femoral heads to reduce post-operative instability [2].

The volumetric wear of MOM is extremely lower than metal on ceramic or polyethylene. However, the particles generated by MOM bearing are significantly smaller than particles of Metal on poly [3, 4].

Metal on Metal Arthroplasty was used commonly until 15 years ago. However, National Registry Data in Australia [5], England, Wales, and Northern Ireland [6], showed that Metal on Metal Hip replacements and resurfacings have significantly higher revision rates compared to Metal on Polyethylene Hip replacements.

The increased rate of MOM arthroplasty revision is thought to be due to the adverse reaction of metal debris released from bearing surface with the surrounding soft tissues which lead to the formation of "pseudotumor" [2].

Trunionosis is another acknowledged cause of Metal on Metal hip arthroplasty failure [7], defined as wear of femoral head-neck interface. It is estimated to account for around 3\% of all revision Total hip arthroplasty [8].
The exact causes of trunnionosis are still poorly understood. However, it is believed that the main factors contributing to its occurrence include wear and corrosion at the modular neckstem taper junction [9-11]. Additionally, Banerjee et al. [12] found that different implant designs and geometries have demonstrated a predisposition to trunnion failure.

Corrosion debris produced at the trunnion Leads to local soft tissue reactions [13, 14], these reactions are clinically and histologically similar to the adverse tissue reactions (ALTRs) seen in MOM [15, 16] and non-MOM bearings [16, 17]. Davies et al. [18] did a comparative study of periprosthetic tissues which obtained at the time of revision of twenty-five cobalt chromium-on-cobalt chromium, nine cobalt chromiumon-polyethylene, and ten titanium-on-polyethylene total hip arthroplasties. Control tissues were obtained from nine osteoarthritic hips at the time of primary total hip arthroplasty, the results showed $68 \%$ of the MOM tissues showed perivascular infiltration, and accumulation of plasma cells in association with macrophages that contained metallic wear-debris particles in $40 \%$.

Pseudotumor is another well known MOM-Arthroplasty adverse reaction, it is defined as non-neoplastic and non-infectious cystic or solid mass associated with a hip arthroplasty [19], the exact natural course of its occurrence is still poorly understood [20]. Patients complain most often of groin pain, hip discomfort, paresthesia, antalgic gait, and/or a palpable mass $[21,22]$. However, the actual rate of THA revision due to symptomatic pseudotumor is only $1.7-5.6 \%$ [21, 23].

\footnotetext{
*Corresponding author: 117223080@umail.ucc.ie
} 


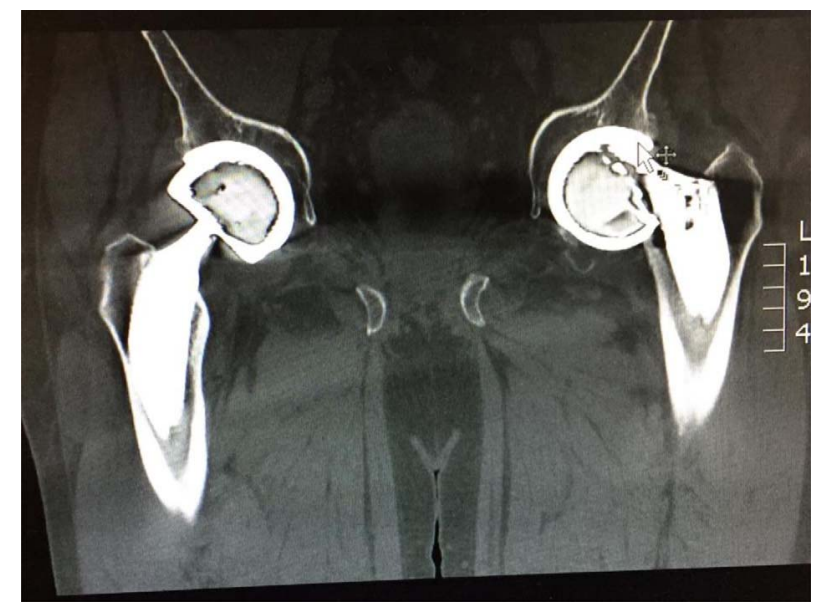

Figure 1. CT scan (Coronal View) showing dislocated femoral head for the trunnion of the femoral neck.

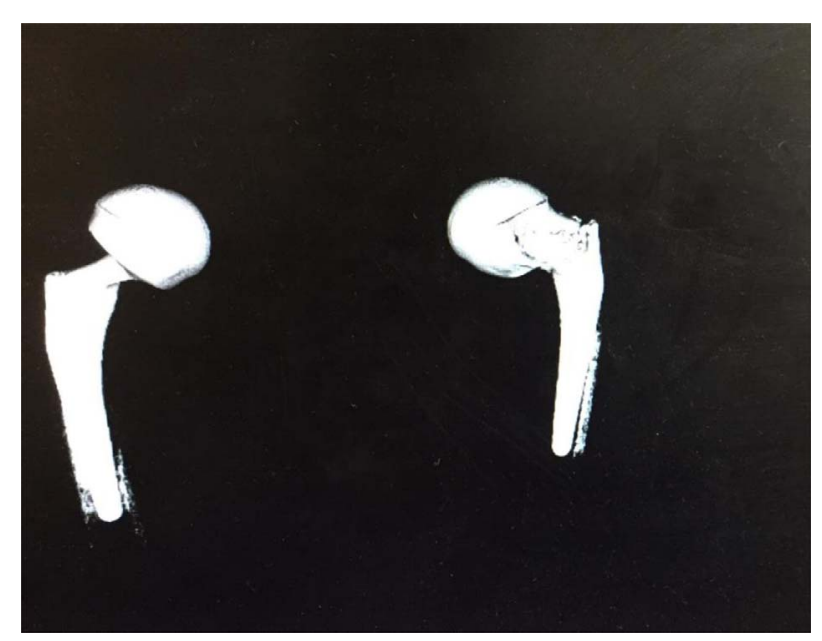

Figure 2. CT scan (3D Construction), showing the dislocation.

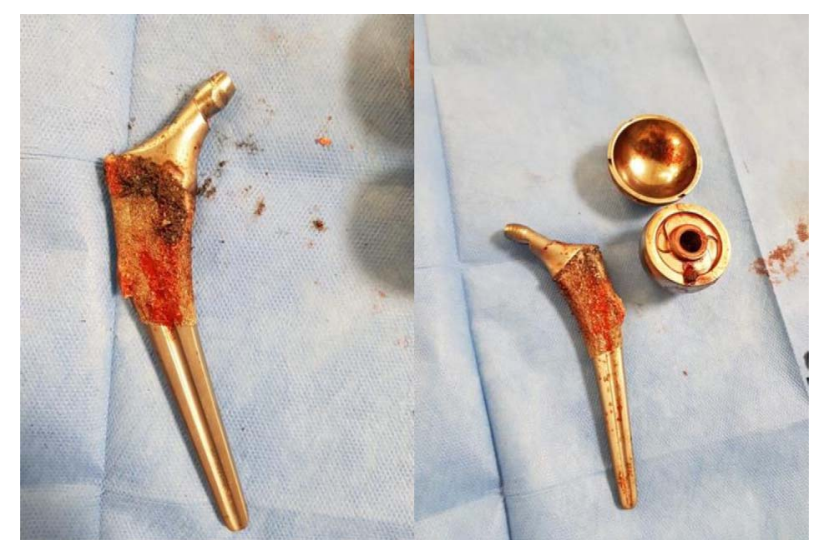

Figure 3. Intra-op pictures of the prothesis, showing the bend at the neck-taper junction.

\section{The case}

Our patient was a 73-year male, and had Mitch Accolade (MoM) total hip replacement (Product of Stryker Company, HQ Based in Michigan, USA) in 2008; he was doing well with no issues or complains until early Jan 2018 when his left leg unfortunately became stuck under the steering wheel while getting out of car; he twisted his left leg and felt a "pop".

Since then he was complaining of crepitations in his left hip as well as shortening in his left leg length, yet he was mobilizing on it.

He had been reviewed at the orthopedic clinic afterward, where a CT scan was performed (Figures 1 and 2) which confirmed implant dissociation.

His Chromium ion level was $70.2 \mathrm{nmol} / \mathrm{L}-3.65 \mathrm{ppb}$ (elevated above $135 \mathrm{nmol} / \mathrm{L}-7$ parts per billion) and his Cobalt level was $253.45 \mathrm{nmol} / \mathrm{L}$ - $14.93 \mathrm{ppb}$ (elevated above $120 \mathrm{nmol})$, which was elevated.

The patient underwent revision left total hip replacement. Intra-op findings included: a large pseudotumor around the prothesis containing metal debris which was excised, advanced

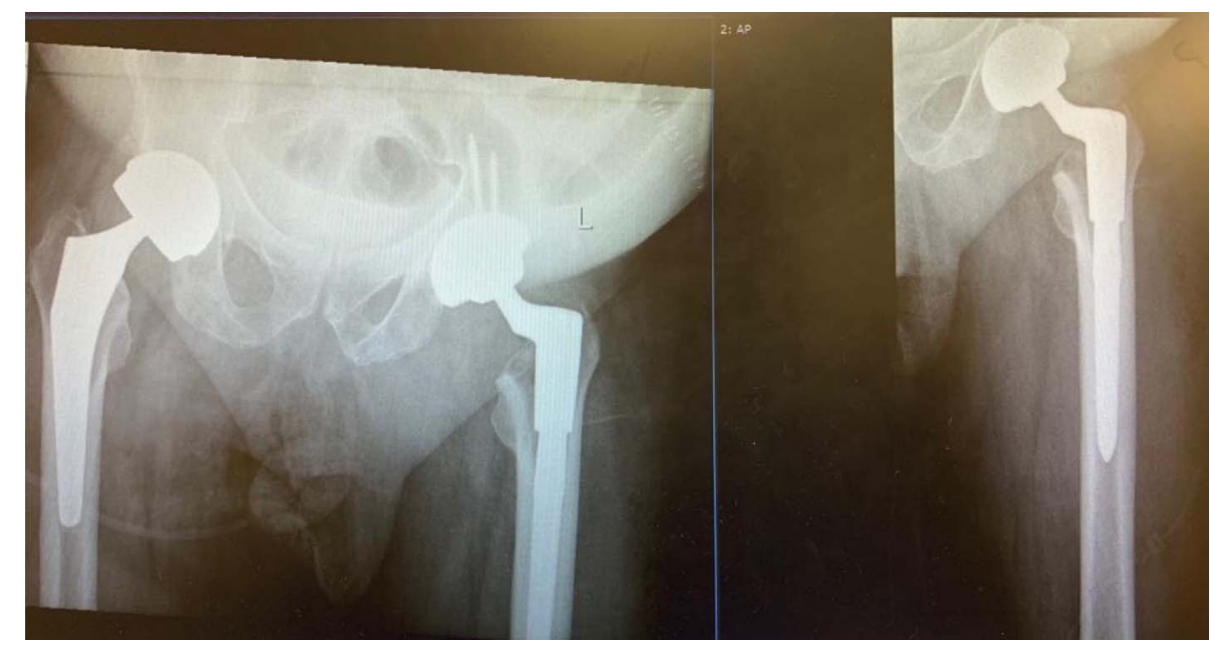

Figure 4. AP pelvis and left hip post-operative check X-rays. 
corrosion around the trunnion with deformed shape (Bending at the neck-taper junction, Figure 3) and disengagement of the femoral head from the femoral stem.

Reclaim conical cementless femoral stem at revision surgery with a pinnacle (Gripton) acetabular shell (Product of DePuy Synthes Company - HQ based in Raynham, USA) was used (Figure 4).

Post-op, the patient did very well with physio and rehab, and he was discharged home a few days later.

\section{Conclusion}

MOM Bearings on Hip Arthroplasty were popular and were commonly used world-wide due to its enhanced wear profile and post-op stability. However, this enthusiasm has declined significantly recently because of its serious complications, such as trunnionosis, elevated serum metal ion levels, aseptic lymphocyte-dominated vasculitis-associated lesions (ALVAL), pseudotumor formation, and subsequent soft tissue and bone destruction.

Trunnionosis is a well-known complication of MOM Total Hip Arthroplasty, the exact cause of which is still poorly understood. However, it is believed that contributing factors include wear between MOM modular junctions [1], corrosion and fretting damage [2], and the release of metal ions or particulate debris from affected components [3].

Failure of the bi-modular stems with cobalt-chrome necks and titanium taper has been widely reported [24-28]. The mechanism of failure of the bi-modular stems is mainly MACC (Mechanically assisted Cervice Corrosion) between the taper and the neck.

To our knowledge, in all prior reported cases of bi-modular femoral stem failures, patients have had broken the femoral stem at neck-taper junction with high serum ion levels of cobalt and chromium. Here is another example of Bi-modular stem failure that presented as head disengagement from the stem without a fracture at the taper-neck junction. We believe this is the only example of Metal on metal modular stem failure that involves head disengagement from the stem without fracture of the taper-neck junction.

\section{Conflict of interest}

The authors declare that they have no conflict of interest.

\section{Financial disclosure}

The authors declare that they have no financial disclosure.

\section{References}

1. Daniel J, Pynsent PB, McMinn DJ (2004 Mar) Metal-on-metal resurfacing of the hip in patients under the age of 55 years with osteoarthritis. J Bone Joint Surg Br 86(2), 177-184.

2. Silverman Edward J, Ashley Blair, Sheth Neil P (2016) Metal-on-metal total hip arthroplasty: Is there still a role in 2016? Curr Rev Musculoskelet Med 9, 93-96.
3. Doorn PF, Campbell PA, Worrall J, Benya PD, McKellop HA, Amstutz HC (1998) Metal wear particle characterization from metal on metal total hip replacements: transmission electron microscopy study of periprosthetic tissues and isolated particles. J Biomed Mater Res 42, 103-111.

4. Topolovec M, Cor A (2014) Milosev I. Metal-on-metal vs. metal-on- polyethylene total hip arthroplasty tribological evaluation of re- trieved components and periprosthetic tissue. J Mech Behav Biomed Mater 34, 243-252.

5. Australian Orthopaedic Association (2015) Metal on Metal Bearing Surface Total Conventional Hip Arthroplasty. Supplement Report 2014. National Joint Replacement Registry. Available online: https://aoanjrr.dmac.adelaide.edu.au/documents/ 10180/172288/Metal\%20on\%20Metal\%20Total\%20Conventional $\% 20$ Hip\%20Arthroplasty (accessed on 17 June 2015).

6. National Joint Registry for England, Wales and Northern Ireland (2015) 11th Annual Report 2014. Available online: http://www. njrreports.org.uk/Portals/0/PDFdownloads/NJR 11th Annual Report 2014.pdf (accessed on 17 June 2015).

7. Pastides PS, Dodd M, Sarraf KM, Willis-Owen CA (2013) Trunnionosis: a pain in the neck. World J Orthop 4(4), 161.

8. Drummond J, Tran P, Fary C (2015 Jun 26) Metal-on-metal hip arthroplasty: a review of adverse reactions and patient management. J Funct Biomater 6(3), 486-499.

9. Pivec R, Meneghini RM, Hozack WJ, Westrich GH, Mont MA (2014) Modular taper junction corrosion and failure: how to approach a recalled total hip arthroplasty implant. J Arthroplasty 29(1), 1.

10. Gilbert JL, Buckley CA, Jacobs JJ (1993) In vivo corrosion of modular hip prosthesis components in mixed and similar metal combinations. The effect of crevice, stress, motion, and alloy coupling. J Biomed Mater Res 27(12), 1533.

11. Langton DJ, Jameson SS, Joyce TJ, Gandhi JN, Sidaginamale R, Mereddy P, Lord J, Nargol AV (2011) Accelerating failure rate of the ASR total hip replacement. J Bone Joint Surg Br 93 (8), 1011.

12. Banerjee S, Cherian JJ, Bono JV, Kurtz SM, Geesink R, Meneghini RM, Delanois RE, Mont MA (2015) Gross trunnion failure after primary total hip arthroplasty. J Arthroplasty 30(4), 641.

13. Urban RM, Jacobs JJ, Gilbert JL, Galante JO (1994) Migration of corrosion products from modular hip prostheses. Particle micro- analysis and histopathological findings. J Bone Joint Surg Am 76(9), 1345.

14. Jacobs JJ, Urban RM, Gilbert JL, Skipor AK, Black J, Jasty M, Galante JO (1995) Local and distant products from modularity. Clin Orthop Relat Res 319, 94.

15. Campbell P, Ebramzadeh E, Nelson S, Takamura K, De Smet K, Amstutz HC (2010) Histological features of pseudotumor-like tissues from metal-on-metal hips. Clin Orthop Relat Res 468(9), 2321.

16. Mahendra G, Pandit H, Kliskey K, Murray D, Gill HS, Athanasou N (2009) Necrotic and inflammatory changes in metal-on-metal resurfacing hip arthroplasties. Acta Orthop 80 (6), 653.

17. Gill IP, Webb J, Sloan K, Beaver RJ (2012) Corrosion at the neck-stem junction as a cause of metal ion release and pseudotumor formation. J Bone Joint Surg Br 94(7), 895.

18. Davies AP, Willert HG, Campbell PA, Learmonth ID, Case CP (2005) An unusual lymphocytic perivascular infiltration in tissues around contemporary metal-on-metal joint replacements. J Bone Joint Surg Am 87(1), 18. 
19. Davis Derik L, Morrison James J (2016) Hip arthroplasty pseudotumors: pathogenesis, imaging, and clinical decision making. J Clin Imag Sci 6, 17. Published online 2016 Apr 29.

20. Almousa SA, Greidanus NV, Masri BA, Duncan CP, Garbuz DS (2013 Dec) The natural history of inflammatory pseudotumors in asymptomatic patients after metal-on-metal hip arthroplasty. Clin Orthop Relat Res 471(12), 3814-3821.

21. Bisschop R, Boomsma MF, Van Raay JJ, Tiebosch AT, Maas M, Gerritsma CL (2013) High prevalence of pseudotumors in patients with a Birmingham Hip Resurfacing prosthesis: a prospective cohort study of one hundred and twenty-nine patients. J Bone Joint Surg Am 95, 1554-1560.

22. Scully WF, Teeny SM (2013) Pseudotumor associated with metal-on-polyethylene total hip arthroplasty. Orthopedics 36, e666-e670.

23. Berend KR, Morris MJ, Adams JB, Lombardi AV Jr (2012) Metal-on-metal hip arthroplasty: Going, going, gone... affirms. J Bone Joint Surg Br 94(11 Suppl. A), 75-77.
24. Meftah M, Haleem AM, Burn MB, Smith KM, Incavo SJ (2014) Early corrosion-related failure of the rejuvenate modular total hip replacement. J Bone Joint Surg Am 96, 481.

25. Atwood SA, Patten EW, Bozic KJ, Pruitt LA, Ries MD (2010) Corrosion-induced fracture of a double-modular hip prosthesis: a case report. J Bone Joint Surg Am 92, 1522.

26. Cooper HJ, Urban RM, Wixson RL, Meneghini RM, Jacobs JJ (2013) Adverse local tissue reaction arising from corrosion at the femoral neck-body junction in a dual-taper stem with a cobalt-chromium modular neck. J Bone Joint Surg Am 95,865 .

27. De Martino I, Assini JB, Elpers ME, Wright TM, Westrich GH (2015) Corrosion and fretting of a modular hip system: a retrieval analysis of 60 rejuvenate stems. J Arthroplasty 30, 1470.

28. Spanyer J, Hines J, Beaumont CM, Yerasimides J (2016 May) Catastrophic femoral neck failure after THA with the Accolade $^{\circledR}$ I stem in three patients. Clin Orthop Relat Res 474(5), 1333-1338.

Cite this article as: Elsheikh MFH \& Gul R (2019) Femoral head disengagement from Accolade femoral stem in MOM Arthroplasty: a case study and literature review. SICOT-J 5, 30 